\title{
Bio-treatment and water reuse as feasible treatment approaches for improving wastewater management during flotation of copper ores
}

\author{
LM Shengo ${ }^{1,2} \cdot$ WNC Mutiti $^{2}$
}

Received: 9 February 2016/Revised: 15 May 2016/ Accepted: 12 July 2016/Published online: 26 July 2016

(C) Islamic Azad University (IAU) 2016

\begin{abstract}
Established and emerging technologies for treatment of flotation wastewaters are compared and discussed in the context of their applicability during the management of wastewaters from $\mathrm{Cu}-\mathrm{Co}$ ores processing through flotation in the Katanga province of the Democratic Republic of Congo. The effects from water recycling on water quality and flotation performance are briefly presented in parallel. The ore processing schemes and the wastewater management practices at two operational concentrators are illustrated as study cases and their peculiarities outlined. A reference to a copper concentrator in a nearby Zambia is addressed for comparative purpose. Based on analysis of the findings, the clarification, biotreatment inside the tailing ponds or the use of constructed wetlands as polishing stage prior to water reuse are suggested as feasible treatment approaches in view improving the management practice of flotation wastewaters during the dressing of copper ores in the Katanga province.
\end{abstract}

Keywords Ore dressing - Flotation wastewaters . Management practice improvement $\cdot$ Bio-treatment $\cdot$ Water reuse

LM Shengo

shengolutandulamichel@yahoo.fr

1 The Chemical and Metallurgical Processing Unit, Department of Materials Science, Higher School of Industrial Engineering, Kasapa Road, P.O.Box. 1825, Lubumbashi, Katanga, The Democratic Republic of Congo

2 The Inorganic Chemical Unit, Department of Chemistry, Faculty of the Sciences, University of Lubumbashi, Likasi Avenue, P.O.Box. 1825, Lubumbashi, Katanga, The Democratic Republic of Congo

\section{Introduction}

Flotation is a three-phase process to separate valuable minerals based on differences in surface properties of the particles after milling of metallic ores (Banyak 1998). Since it takes place in the aqueous phase, flotation reagents and fine particles inevitably report in the process streams. Following the stages of ore crushing and milling, a large volume of matter has to be treated by flotation, therefore maintaining an optimal flotation scheme could be summarized as conversion of quantity of valuable minerals from a mining operation into a concentrate product with a maximum degree of upgrade and minimum impact to the environment.

After solid/liquid separation, process water from flotation is often recycled in closed circuit, which is gradually leading to perturbations in metallurgical results due to accumulation of residual reagents, changes in water salinity and increase in amount of slimes (Coetzer et al. 2003; Johnson 2003a, b; Levay et al. 2001; Muzenda 2010; Namita and Natarajan 1998a; Nedved and Jansz 2006; Rao and Finch 1989; Sandenbergh and Wei 2007; Shengo et al. 2014; Liu et al. 2013). In response to that, large number of concentrators is placing considerable efforts for studying the effects from water recycling schemes on the metallurgical recoveries, which inevitably reflects on the sustainable use of water resources in the concerned areas (Coetzer et al. 2003; Levay et al. 2001; Mudd 2008; Sandenbergh and Wei 2007; Liu et al. 2013). Such issues are at present considered by the mining operators in the Katanga province of the DRC (Lutandula and Kalenga 2014), which belongs to the Central African Copper belt. This metallogenic region extends over more than $700 \mathrm{~km}$ from Zambia through the Katanga province in the DRC and comprises a good number of the richest copper deposits in the world 
containing cobalt as the main economically recoverable coproduct (Fig. 1).

Consequently, the DRC is often referred to as "a geological scandal" and its Copper belt region remains an area of intensive mining activities since several decades (The Netherlands institute for Southern Africa (NISA) 2006; Verlinden and Cuypers 1956). These activities have recently seen a strong impetus due to the increased demand for metal commodities from the fast-growing economies in Asia and consequently have led to accumulation of large amounts of both solid and liquid mine wastes (Crowson 2006; Lutandula and Banza 2013; N'Sakila 2008; Swartz et al. 2009). It is important pointing out that, in the majority of the cases, the disposal of wastes coming from metal extraction and beneficiation activities in the Katanga province used to have detrimental effects on environment (Kalenga et al. 2006; Lutandula and Kalenga 2014; SNCLavalin International 2003; Vande Weghe et al. 2005). At present, there are mining companies which have opted for up-to-date methods in management of their tailings and process wastewaters, whilst other continue to use classical methods (Chadwick 2008; Digby Wells and Associates 2008; Kalenga et al. 2006; TFM 2010). It has been reported that copper and cobalt met in tailings can be economically recovered through their reprocessing (Chadwick and Cattaneo 2005; Kalenga et al. 2006; Lutandula and Kalenga 2014). It is important to note that in the Katanga province, an interest in process wastewater reuse exists (SNCLavalin International 2003). With the objective to reduce reagents related costs, mineral processing practitioners are wondering if and how a recovery of residual flotation reagents could be accomplished by means of process waters reuse (SNC-Lavalin International 2003; Liu et al. 2013; Lutandula and Kalenga 2014). With the abovementioned concerns on the background, the present study has been undertaken with the aim to review the contemporary practices in treatment and recycling of process waters from mineral extractive sector and to evaluate the feasibility of their implementation in the context of the Katanga region. Another incentive to achieve the present research is the fact that a sound management of wastewaters from the copper minerals dressing through flotation could enable lowering the footprint of the mineral processing industry on the environment, implementing the safeguarding of watercourses presently used as spillways for flotation effluents and contributing to the sustainable use of water resources.

\section{Background and discussion}

\section{Process water recycling in the mineral industry}

The recycling of process waters in industry dates back almost a century ago. In 1940, the municipal wastewaters of the city of Baltimore in USA have been recycled within the steel industry by Bethlehem Steel Inc. (Exall 2004; Johnson 2003a, b). Nowadays the treatment of industrial waters is viewed as an integral part of the sound management of aquatic resources (Anderson 2000; Dobson and Burgess 2007; European Environmental Agency 2009; Mudd 2008; Norgate and Lovel 2004; Schoengold and
Fig. 1 Copper deposits located in the Zambia-Congo Copperbelt

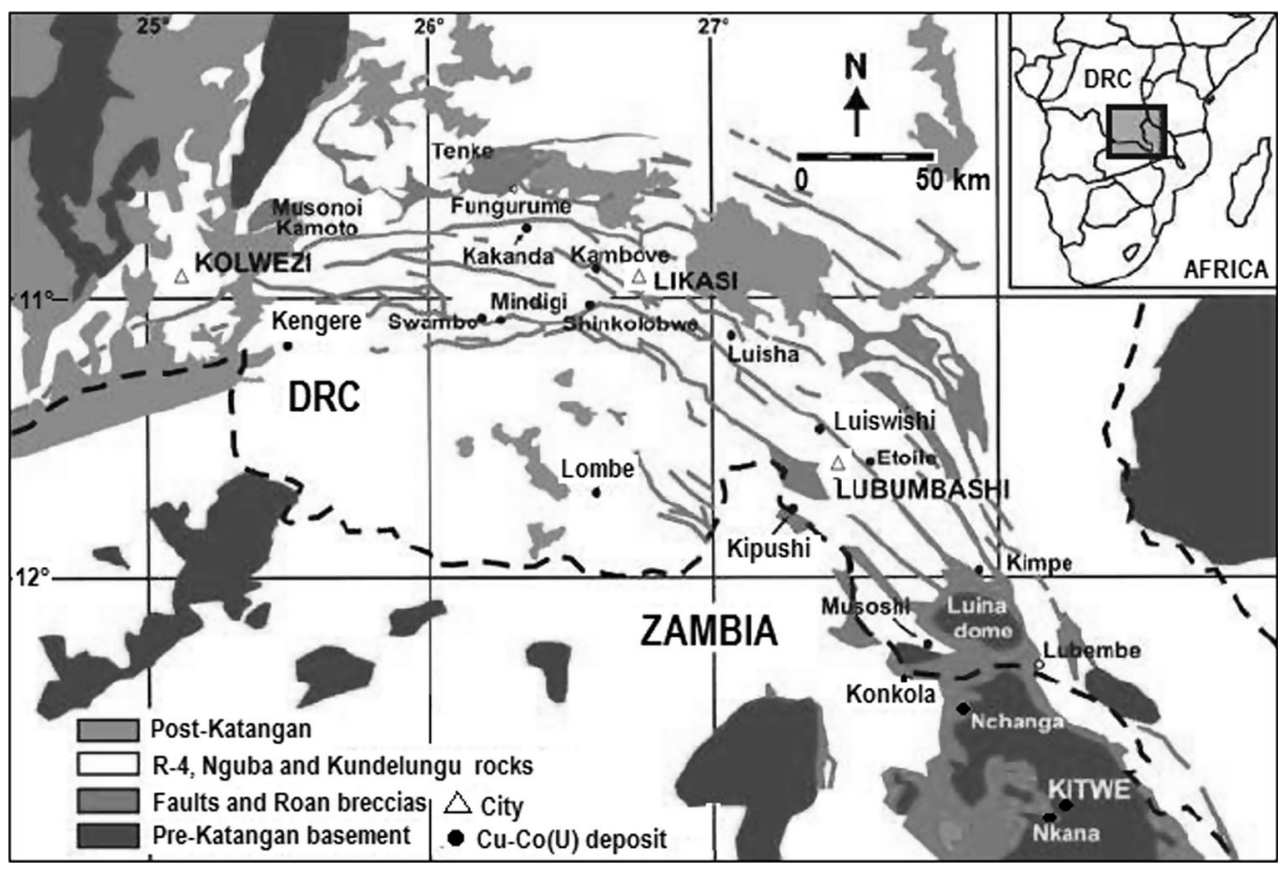


Zilberman 2008; Zeman et al. 2006) and process water recycling has became a "must" in arid and semi arid regions of the world (Dobson and Burgess 2007; Dolnicara et al. 2012; Johnson 2003a, b; Oudshoorn 1997; UNESCO 2003). Mining and the mineral industries are notorious by their significant consumption of water (Wotruba 2008); therefore, process water recycling and reuse within these sectors, apart from having direct economic implications, contribute to lowering their footprint upon the environment (Anderson 2000; Dobson and Burgess 2007; Fatta and Kythreotou 2005; Johnson 2003a, b; Nedved and Jansz 2006; World Bank Group 1999).

A mineral processing plant treating polymetallic leadzinc ores is requiring about $6000 \mathrm{~L} / \mathrm{h}$ of water for ore grinding and flotation (Jennett and Wixson 2005). This huge water demand has forced the majority of Chilean mining companies to treat and reuse their process wastewaters until complete quality deterioration before letting them to be ultimately stocked in ponds (Bosse et al. 2007)

The Canadian mineral industry is recycling since 1970 from 50 to $75 \%$ of its process waters (Rao and Finch 1989). Statistical data for the Canadian industry as on 1996 indicated an annual water consumption of 518 million cubic metres, with nearly half consisting of water recycled by the minerals extraction sector (Exall 2004). Another example is Chile, where between 2003 and 2004, the water consumption by North Division of Codelco has been estimated as 55 millions of cubic metres, with more than $80 \%$ of this volume being recycled and only $6 \%$ released to the environment (Bosse et al. 2007). The Chilean mining industry especially the concentrators located in the desert region of Atacama suffers from severe lack of water resources. In response to this situation, the Esperanza copper-gold project situated in Atacama region is using for its metal extraction process untreated seawater transported by four pumping stations from $145 \mathrm{~km}$ distance (Chadwik 2009; Saavedra 2012). As a whole, about $67 \%$ of the wastewaters released by the Chilean mining industry are either stocked in ponds or reused after treatment by variety of techniques such as neutralization and sedimentation, flocculation, dissolved air flotation, etc. (Bosse et al. 2007). In such a manner, the implementation of wastewater treatment stages has enabled the Chilean copper industry to reuse their process waters eight times in average.

Australia being the driest continent in the world is another example for the importance of process water reuse (Dolnicara et al. 2012; Laurenson et al. 2010). Recent studies have indicated that provided process waters are treated and reused, the Australian mineral industry has succeed to lower its fresh water consumption from the usually $3-1.8 \mathrm{~m}^{3} /$ ton of ore to as less as $1 \mathrm{~m}^{3} /$ ton (Johnson 2003a, b; Nedved and Jansz 2006). The degree of water recycling within the mining sector in the year of 2000 has been estimated close to $37 \%$, but with climate previsions even worse for the years to come, this figure should certainly be exceeded (Dillon 2000; Dolnicara et al. 2012). Johnson (2003a, b) has addressed with more details the issues in maximization of recycling of water in a mineral processing plant and the practices concerning water reuse in Australia.

At the Boliden Mineral $\mathrm{AB}$ in Sweden, proportions about $53 \%$ of the process water were recovered from the tailings pond and the concentrate thickeners (Rao and Finch 1989). At the Raglan nickel-copper mine in Quebec Canada, about $400 \mathrm{~m}^{3}$ of process water was hourly supplied in the flotation cycle, in order to minimize fresh water addition. The fact that this mine is located in the arctic region, which is a cool and fragile environment, has enabled water treatment to be realized by natural cooling and desalination. In such a way, about $20,000 \mathrm{~m}^{3}$ process wastewaters containing lime as residual reagent were stocked inside an abandoned underground mine before being recycled.

It is worth to mention that although at laboratory scale a complete wastewater-recycling loop has been successfully demonstrated at the Transbaikal region in the former USSR for the case of fluorite flotation, the scaling-up at industrial level remains a difficult task due to perturbations on the process efficiency (Sychkov and Bochkarev 1976). In this study, synthetic wastewaters simulating a discharge from concentrate thickening and tailings dewatering circuits with suspended solids of $300-400 \mathrm{mg} / \mathrm{L}$ have been tested. The wastewaters have been reused several times without registering adverse effects on fluorite flotation. However, the situation could be quite different if one considers the practice of wastewater reuse during flotation of lead-zinc ores with calamine and cerussite as the valuable metals main bearing minerals. In this instance, the recycling of the untreated wastewater back to flotation has led to decrease of lead grade in lead concentrate by $62 \%$ in comparison with the one obtained when fresh water was used (Rao and Finch 1989). In contrast, zinc flotation has been affected to a lesser extent by the variation in water quality. Similarly, during water reuse in flotation of complex lead-zinc sulphides from the Rosh Pinah (Namibia), Sandenbergh and Wei (2007) have noticed an increased presence of zinc in the lead concentrate showing explicitly the loss in the collector selectivity arising due to the unwanted activation of sphalerite by copper, lead and silver ions present in the pulp water. The perusal of these results indicates that fluctuations in water quality do influence flotation performance, but in a different degree highly depending on the type of ore treated and the reagents suite (Coetzer et al. 2003; Sandenbergh and Wei 2007; Shengo et al. 2014; Liu et al. 2013). Regarding the effect of water recycling on 
reagents addition rate, a study performed at the Samarco mine in Brazil has shown that wastewater reuse during the reverse flotation of haematite has allowed to halve the consumption of cationic collector resulting in an improvement of the process economy (Stapelfeldt and Fernandes Lima 2001; Liu et al. 2013).

Before being returned back to milling, process waters are usually subjected to treatment by either single or a combination between more than two methods (Boeglin 1974; Sandenbergh and Wei 2007). The choice of a given method and the extent up to which process water is recycled in a process should be well justified, because they do affect key physicochemical flotation parameters and in such a way the final metallurgical results of the concentrator (Liu et al. 2013). Table 1 presents summary data about the compounds commonly met in clarified process water after flotation and their potential impacts on flotation performance showing explicitly the importance of designing strategies that can enable mitigating detrimental effects from the recycled water chemical components.

Some strategies have been designed by the mineral processing practitioners in view combating the adverse effects from water recycling on flotation efficiency. Among them, one finds the use of the recycled water in mixture with fresh water, the feed water conditioning with adequate chemicals that can positively influence the minerals surface properties, the chemical and physical purification of the process wastewater as well as the biological treatment followed by ozonation particularly when one intends to float sulphide minerals (Abramov 2005; Muzenda 2010; Slatter et al. 2009; Liu et al. 2013; Xingyu et al. 2013). However, concerning flotation of oxide ores and particularly those of copper from the Katanga province, the data in relationship with the methods used in view improvement of the process efficiency during water recycling are scarce when compared to flotation of sulphides (Shengo et al. 2014).

Excellent published studies are suggesting that certain flotation mills are operating with nearly zero discharge of wastewaters to the environment (Johnson 2003a, b), whilst others are either releasing to the environment wastewaters with total dissolved solids below $1000 \mathrm{ppm}$ or operating in closed circuit in order to comply with environmental regulations and contribute to sustainable water resources management (Levay et al. 2001; Mudd 2008).

\section{Methods for treatment of flotation wastewaters}

The first treatment stage for the flotation tailings, usually met as diluted pulps, is often accomplished by solid-liquid separation with the fine solids being left to sediment during relatively long time periods inside a tailings pond (Boeglin 1974; Nedved and Jansz 2006). Nevertheless, the physical separation by sedimentation in tailings pond has never been viewed in all cases as sufficient step for guarantying the desired purification degree for the waters associated with flotation tailings and particularly for their reuse in a given process (Erten-Unal and Wixson 1999; Johnson 2003a, b). In order to accomplish more profound water purification, flocculants should be added and large infrastructures and significant residence times should be available, which often is not feasible from practical to economical viewpoint (Boeglin 1974). Moreover, inorganic and organic impurities or chemical species that can be met in ionic forms or as complexes could not be totally removed via simple gravity precipitation. Studies have shown that certain process

Table 1 Compounds met in the flotation process waters and their potential effects

\begin{tabular}{ll}
\hline Compounds & Effects on mineral flotation
\end{tabular}

Residual flotation reagents and sulphur bearing compounds (amine, carboxylate and sulphate collectors, sulphidizing reagents, frothers etc.) or their degradation products like dixanthogenates

Other organic matters (flocculants, emulsifying agents, etc.) as well as oil spillages from mining equipments and trucks, etc. (mine waters recycling)

Metallic ions $\left(\mathrm{Cu}^{2+}, \mathrm{Fe}^{2+}, \mathrm{Pb}^{2+}\right.$, etc. $)$ due to oxidation of sulphide minerals and alkaline earth ions $\left(\mathrm{Ca}^{2+}, \mathrm{Mg}^{2+}\right.$, etc. $)$

Microorganisms
Disturbances on flotation due to the loss in the reagents selectivity and adverse depression of valuable minerals (Bosse et al. 2007; Namita and Natarajan 1998a; Rao and Finch 1989)

Obtaining of poor concentrates, simultaneous flotation of sulphides and oxides, slimes and silicates. Adverse changes in the pulp $\mathrm{pH}$ and redox potential due to uncontrolled surface phenomena (Rao and Finch 1989). Changes in the minerals surface charge from negative to positive especially for oxidized ores

Increase in total organic matter contents to above $200 \mathrm{mg} / \mathrm{L}$ in the discharges from the ore milling circuit or in cyclones overflow. High content of organic matter $(>100 \mathrm{mg} / \mathrm{L})$ in scavenging flotation or in overflow derived from the concentrate thickener (Levay et al. 2001)

Sudden mineral activation and increase in gangue reactivity towards flotation collectors, loss in flotation performances and decline in metals recoveries (Rao and Finch 1989)

Changes in flotation response due to alteration of mineral surfaces through bacteria or changes in the pulp pH (Levay et al. 2001) 
waters contain surfactants at high residual concentrations, and their degradation products are physicochemically stable either as emulsions or as colloids that are difficult to separate by settling or filtration (Boeglin 1974; Rubio et al. 2002; Liu et al. 2013). Under certain circumstances, the tailings pond could be viewed as a giant reactor where physicochemical and biological purification processes mainly related to degradation of flotation reagents could take place (Charbonnier 2001; Nedved and Jansz 2006; Liu et al. 2013). Quite often, the quality of the wastewaters leaving the tailings pond does not permit their further utilization in other water demanding sectors, like agriculture for example. If further water use is required, a sophisticated desalination methods like reverse osmosis have to be sought (Bosse et al. 2007).

\section{Chemical treatment}

Generally, the chemical neutralization of process waters makes use of reagents with specific action like $\mathrm{CaO}, \mathrm{Ca}$ $(\mathrm{OH})_{2}, \mathrm{Na}_{2} \mathrm{CO}_{3}, \mathrm{Na}_{2} \mathrm{~S}$, etc., which are either dosed on a single basis or as mixtures (Fu and Wang 2011). Under their action, suspensions are destabilized by electric charges neutralization or particles bridging and the generated precipitates subsequently left to sediment by gravity (Dobson and Burgess 2007). This approach presents an established practice from long time ago and is still in use nowadays (Erten-Unal and Wixson 1999; Malkin and Kuzin 2001; Nedved and Jansz 2006; Rulkens 2007). The method has proved especially useful in treatment acid mine drainage waters (Kilborn Inc 1999; Obreque-Contreras et al. 2015). The precipitation of heavy metal ions by sodium sulphide, during handling of wastewaters from copper and zinc flotation, has been equally successfully demonstrated (Malkin and Kuzin 2001). The principal disadvantage of the chemical treatment is the generation of huge amounts of sludge that requires disposal and often further processing (Potvin 2004; Obreque-Contreras et al. 2015; Rulkens 2007). Moreover, if large volumes of wastewater have to be processed, the relatively high cost of associated reagents could preclude its use.

\section{Physicochemical treatment (flotation)}

Being a well-known mineral separation technique, flotation enjoys a plenty of interesting environmental applications like treatment technique either for sewage or for industrial wastewaters (Anastassakis et al. 2004; Dibrov et al. 1998; Rubio et al. 2007; Żak 2012). In this field, flotation could be practiced like conventional or as dissolved air flotation (DAF) mode (Otadi et al. 2011). Welz et al. (2007) have investigated conventional flotation at a laboratory scale for removal of oils from wastewaters using aluminium sulphate as coagulant at $\mathrm{pH}$ 5.5. After the treatment, oil concentration has been found slightly above the targeted level for industrial wastewaters $(50 \mathrm{mg} / \mathrm{L})$ safe release to the environment. The generic principle of dissolved air flotation (DAF), which lies in the generation of microbubbles from gas-saturated pulp/effluent, has been employed for contaminants removal from process waters during their reclamation (Otadi et al. 2011; Rodrigues and Rubio 2007; Shammas et al. 2010). The contaminants being concentrated in the froth fraction are subsequently skimmed away. This emerging technique claims to remove oils, fats and colloidal particles such as dyes or fine dispersions during their treatment and could hourly handle up to $20,000 \mathrm{~m}^{3}$ of the untreated wastewaters (Otadi et al. 2011; Shammas et al. 2010). On a purely comparative basis, the DAF through its capability to remove effectively finely dispersed solid matters and ultra fine hydrophobic particles from process wastewaters secures much more application prospects than the classical flotation exclusively used in minerals dressing. At the Punta Chungo plant in the mine of Los Pelambres (Chile), effluents are subjected to flotation in order to remove sulphate ions, suspended solids and molybdates and produce water reused for irrigation (Obreque-Contreras et al. 2015).

\section{Selective adsorption}

Among the methods used for wastewaters treatment for reuse, adsorption offers according to type of adsorbent employed (activated carbon, biomass, clay etc.) the possibility for selective elimination of certain compounds from process wastewaters. Their spectra could be very broad colloidal particles, soluble halogenated matters, metallic and phosphate ions, colouration agents, organics, suspended solids, etc. (Awaleh and Soubaneh 2014; Rulkens 2007).

\section{Biological treatment}

The biological methods when practised as membrane bioreactors or bio filters are capable to overcome one of the principal drawbacks of the chemical treatment-the generation of large amounts of sludge (Dobson and Burgess 2007; Mulligan and Gibbs 2003; Obreque-Contreras et al. 2015; Wawrzak and Cablík 2014). Although biological treatment requires regular monitoring, the fact that it is achieved inside biological media and being itself not a source of additional water pollution has ranked it as an economical and environmentally friendly one (Dobson and Burgess 2007; Groudeva 2001; Singh et al. 2011; Vymazal 2010; Wawrzak and Cablík 2014). The biological media could be either artificial or a natural one, the latter stimulated by addition of nutrient or energy sources like lactates, 
pyruvates, formates, malates, acetates or even the organic pollutants themselves (Dobson and Burgess 2007; Potvin 2004; Wawrzak and Cablík 2014). Biological methods could be practised as different systems (membrane bioreactors and biofilters, permeable reactive barriers (PRB) and constructed wetlands). They could be operated either in passive (static flow) or in active contact modes (Department of resources, energy and tourism, water management 2008; Obreque-Contreras et al. 2015). Namita and Natarajan (1998a) provided evidence of biodegradation of flotation surfactants by the species Bacillus polymyxa used as biofilter. In a similar operation mode, biogenically generated sulphides, produced by some bacteria such as Desulfovibrio, Desulfotomaculum, etc., have been used as precipitating agents for the metallic ions found in acid mine drainage waters (Dobson and Burgess 2007; Potvin 2004; Obreque-Contreras et al. 2015; Wawrzak and Cablík 2014). In some cases, by creation of conditions that are favourable to the growth for certain bacteria or plants like green algae blooms, the tailings pond could be transformed into a giant bioreactor (Obreque-Contreras et al. 2015; Shazia Iram et al. 2012; Sterritt and Lester 1979; Liu et al. 2013). The same study indicated that the proliferation of green algae blooms inside the tailings pond reflecting in production of biogenic hydrogen sulphide from the dead algae has led to more than $90 \%$ removal of heavy metals via biosorption and precipitation as sulphides.

Concerning the biological treatment by means of constructed wetlands, it operates on the same principle as the passive sulphate reducing biofilters, but requires larger surface areas (Garcia et al. 2010; Potvin 2004; ObrequeContreras et al. 2015; Vymazal 2010, 2011; Wawrzak and Cablík 2014). Constructed wetlands provide an attractive means for long-term wastewaters management at abandoned mill and mine sites (Kunze et al. 2007; ObrequeContreras et al. 2015; Vymazal 2010, 2011). The application of wetlands for industrial wastewater treatment is looked at by Awaleh and Soubaneh (2014) as a promising alternative apart from their significant merits of having low capital and operating costs compared to other conventional treatment systems.

When metallurgical wastewaters are to be treated, wetlands are usually placed as polishing step after the primary chemical neutralization when the majority of heavy metals are already precipitated (Gaydardjiev et al. 1996; Garcia et al. 2010). At the Doe Run Buick mine in Missouri, USA, the combination of settling in tailings pond and bio-treatment in series of artificially constructed meandering channels and polishing lagoon has led to removal of more than $95 \%$ zinc and manganese along with 50 and $60 \%$ copper and lead, respectively, from the flotation wastewaters (Erten-Unal and Wixson 1999). It should be noted that although biological methods have found application both in the treatment as well as in the recycling of wastewaters from variety of industries, their industrial implementation for treatment and recycling of flotation wastewaters is still to be seen (Galil and Levinsky 2007; Groudeva 2001; Singh et al. 2011). Besides, the presence of bacteria in the treated water can perturb the process functioning particularly in the case of sulphide ores flotation (Johnson 2003a, b; Levay et al. 2001; Liu et al. 2013).

\section{Management of flotation process water in Katanga province}

Whilst the proper management of mineral processing wastewaters has allowed Chilean mineral processing operators to lower fresh water addition in their ore processing circuits to as little as $0.5 \mathrm{~m}^{3} /$ ton of ore (Bosse et al. 2007), the reuse of flotation process waters is still an emerging practice in the Katanga province of DRC. For example, the Boss Mining/ENRC concentrator reuses flotation wastewater and utilizes an advanced water treatment systems involving DAF (Chadwick 2008). In fact, the majority of concentrators operating in Katanga do treat their flotation effluents by classical schemes utilizing settling ponds for process wastewater clarification (Kalenga et al. 2006; SNC-Lavalin International 2003). Two groups of concentrators operating in the mining sector in Katanga province could be distinguished based on the management approaches adapted towards their flotation effluents as shown in Table 2.

From one side, there are recently erected concentrators that have opted for emerging techniques for treatment of their flotation effluents and from other side, the old and the refurbished ones continuing to utilize the established methods. Boss Mining/ENRC, Metal Mining Group Kinsevere and Dikulushi Mill plant are among the concentrators where flotation effluents are treated with emerging technologies or stored in lined ponds in order to recover water for reuse in the milling process (Chadwick 2008; Loshi 2012; Mawson West Ltd 2011). For the sake of illustration of concentrators belonging to the second group, the Kambove concentrator and the new concentrator in kipushi (NCK) are presented as examples. The former has been built during 1963-1964, whilst the latter one has started operation in 1994 after major refurbishing (Kalenga et al. 2006; Lutandula and Banza 2013; SNC-Lavalin International 2003). Both their effluents management systems have been designed based on settling ponds, following a model adopted by the largest state-owned mining company named the "Gécamines". In this model, the effluents storage facilities consist of tailings impoundments, which are designed to perform a number of functions (EPA 1994) including removal of suspended solids by sedimentation, precipitation of heavy metals as hydroxides, 
Table 2 Process waters management at some concentrators in Katanga

\begin{tabular}{llll}
\hline Concentrator & Age & State/category & Process water management method \\
\hline Boss mining/CAMEC & - & Operating/refurbished & DAF for recycling and to Dikuluwe river \\
Ancient concentrator in Kipushi & 1935 & Abandoned/ancient & Release to Kafubu river \\
Kolwezi concentrator & 1941 & Operating/refurbished & Release to Kamatete river \\
Kambove concentrator & 1963 & Operating/ancient & Release to Kabambankola river \\
Kamoto concentrator & 1968 & Operating/refurbished & To Luilu, Kalemba and Musonoi rivers \\
Musoshi concentrator & 1972 & Abandoned/ancient & Release to Kafubu river \\
New concentrator in Kipushi & 1994 & Operating/refurbished & Release to Kafubu river \\
Dikulushi mill plant & 2004 & Operating/new & Storage in a lined pond and recycling \\
MMG Kinsevere HMS-plant & 2006 & Operating/new & Storage in a lined pond and recycling \\
\hline
\end{tabular}

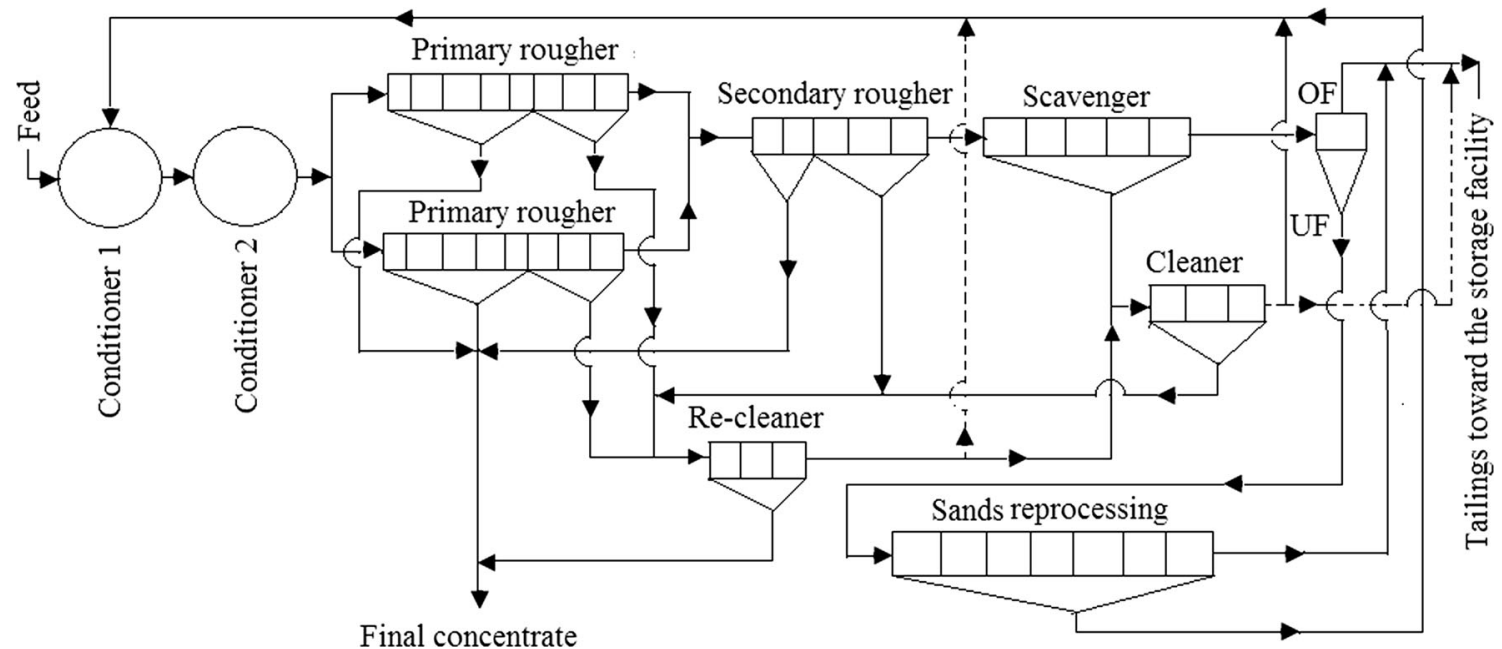

Fig. 2 Kambove concentrator flow sheet

permanent containment of settled tailings, equalization of wastewater quality, stabilization of some oxidizable constituents (e.g., thiosalts, cyanides, flotation reagents), etc. However, it is worth stressing that the inconsistent treatment performance related to seasonal variations in biooxidation efficiency remains one of the major disadvantages of tailings impoundments used in Katanga (EPA 1994; Liu et al. 2013). As a matter of fact, even if in the majority of the cases the contents of heavy metals in water released to rivers rarely surpass the limits defined by the mining regulation of the DRC, the riparians often complain about the liberation of gases with the smell recalling the rotted-eggs, especially during the warm season. These gases are due to bio-oxidation of the sulphur-bearing compounds arising out of tailings impoundments. Among the concerned compounds, one finds the residual hydrogen sulphide and xanthates driven in the rivers by the process waters showing explicitly the necessity to improve practices in the management of the mineral processing effluents and to update the present mining regulation (EPA 1994;
Journal Officiel de la République Démocratique du Congo 2003; Lutandula and Kalenga 2014).

\section{Mineral processing practice at Kambove and NCK concentrators}

In the past, the Kambove concentrator was processing about 4200 tonnes per day of the ROM ores from the Shanguruwe, Kamfundwa and Kamoya open pits as well as from the Kambove underground mine in order to produce concentrates grading 15-20 \% Cu and 4-5\% Co. In 2003, it has handled about 2500 tonnes of ores daily, which represents about $60 \%$ of its initial handling capacity due to the ageing of the facilities (Kalenga et al. 2006; SNCLavalin International 2003). With the lowest recoveries of the valuables metals in the final concentrate $(50-60 \% \mathrm{Cu}$ and $30-40 \% \mathrm{Co}$ ) never achieved in the past, the handling capacity of the Kambove concentrator is presently maintained around 3000 tonnes per day. It is operated by the "Gécamines" using a flow sheet (Fig. 2) that was designed 


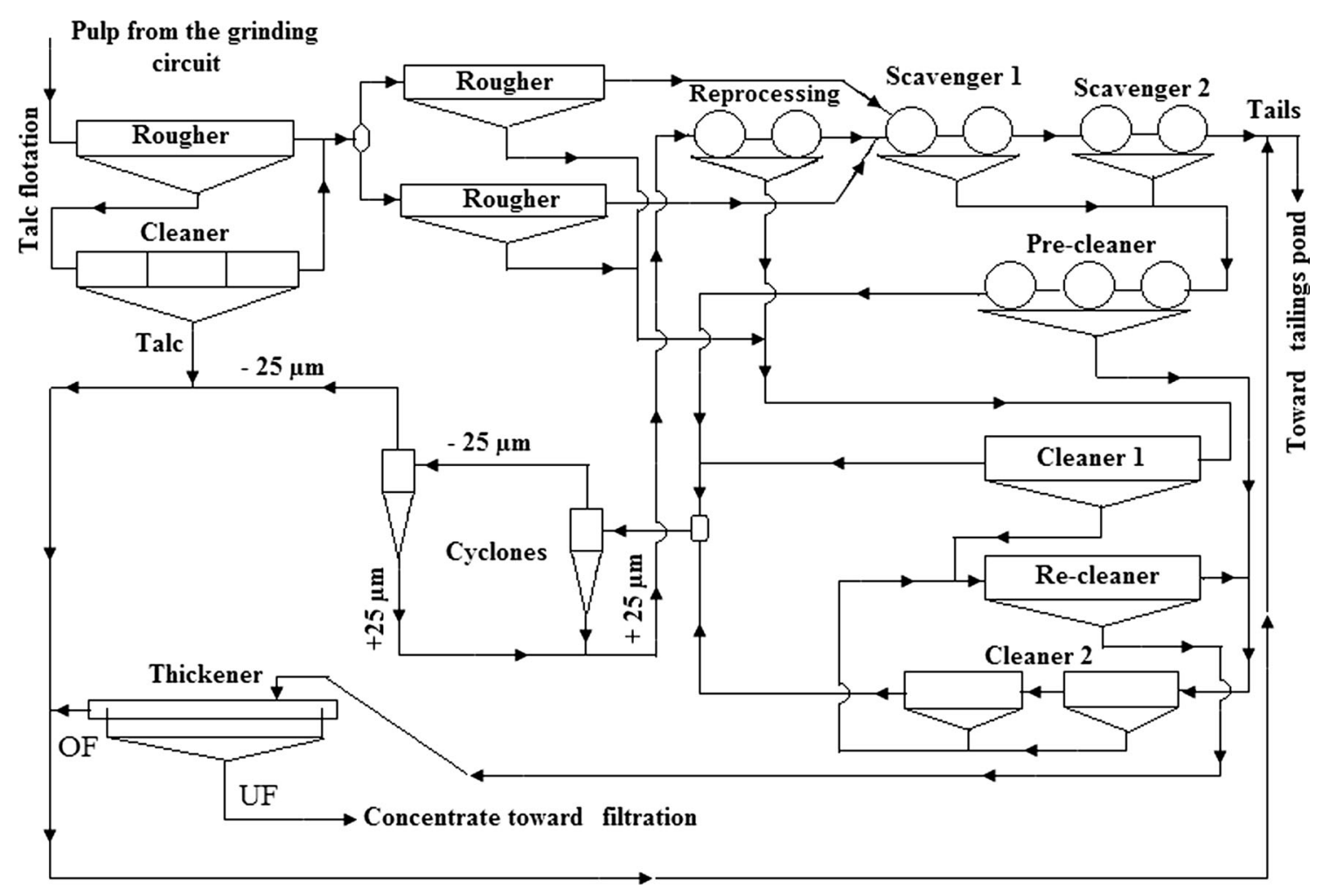

Fig. 3 New concentrator in Kipushi flow sheet

to process the ROM ores from the Kamfundwa deposit where the mined areas mineralization exists in the form of scales with the surface extending over $1.5 \mathrm{~km}$ and the width varying between 200 and $900 \mathrm{~m}$.

The concerned scales are intersected by the barren dolomite rocks (5\%) and host the deposit mineralization in the oxidized area $(95 \%)$ consisting mainly of malachite and heterogenite accompanied by pseudo malachite, cuprite as well as chrysocolla in minor proportions. As for the New Concentrator in Kipushi, it was operated until 2012 using a process (Fig. 3) enabling to handle and process daily about 1750 tonnes of oxidized copper-cobalt ores from the Luiswishi deposit in order to produce concentrates grading $25-30 \% \mathrm{Cu}$ and $7-8 \%$ Co, respectively (NCK 2006, 2008; Nyrenda 2006).

The deposit of Luiswishi is listed among the most important copper deposits mined in Katanga. Its reserves of copper and cobalt are estimated at 7.5-8 million tons present mainly in the form of oxide minerals rich in talc and hosted in the clayey and dolomite sediments including bornite, carollite and heterogenite (Coakley 2001; NCK 2008). The primary mineralization of Luiswishi comprises mainly chalcopyrite in the disseminated state and carollite (Katwika 2012). Tables 3 and 4 are summarizing the type and the reagents dosages used at Kambove and NCK, respectively.
At Kambove, the concentrator utilizes a mixture of synthetic fatty acids under the trade name of "Rinkalore" in combination with traditional flotation reagents during the beneficiation of malachite and heterogenite contained in the ROM ore (Table 3). This approach known also as the "hybrid flotation" is based on a partial replacement of the more costly reagent consisting of sodium hydrogen sulphide by the synthetic fatty acids in order to obtain concentrates with higher copper grades (ca. $11 \%$ ). The concerned acids play the role of the secondary collector. Indeed, the flotation circuit used at Kambove (Fig. 2) has been designed in such a way that the concentrate from the primary rougher cells (graded $10-14 \% \mathrm{Cu}$ and 6-7 \% Co) is directly recovered after its thickening and dewatering, whilst the roughing flotation tails is subjected to reprocessing to produce a re-cleaner concentrate (Banza 2007; Kanku 2008; Lutandula and Banza 2013). At the NCK, the technological emphasis is placed on securing high cobalt recovery using classical flotation circuit encompassing the talc removal, sulphidization of oxide minerals and their recovery by means of xanthate collectors (Table 4). Therefore, the roughing flotation concentrate is subjected to pre-cleaning, cleaning and re-cleaning to obtain the final concentrate as shown in Fig. 3 (NCK 2008). However, it is important mentioning that the NCK consumes more chemicals because the process design enables the 
Table 3 Flotation reagents used at the Kambove Concentrator

\begin{tabular}{lll}
\hline Reagent type and concentration & Dosage rate $(\mathrm{g} / \mathrm{t}$ of ore) & Daily consumption rate $(\mathrm{kg} / 2500$ tonnes) \\
\hline Slimes dispersant-sodium silicate $30 \%$ & 250 & 625 \\
Frother-Sinfroth G41 $100 \%$ & 10 & 25 \\
Modifier-sodium carbonate $30 \%$ & 50 & 125 \\
Sulphidizer-sodium sulfhydrate $36 \%$ & $3000-3500$ & $7500-8750$ \\
Collector (primary)-potassium amyl xanthate 10\% & $300-350$ & $750-875$ \\
Collector (sec.)-mixture gasoil $(90 \%)$ and Rinkalore $(10 \%)$ & 150 & 375 \\
\hline
\end{tabular}

Table 4 Flotation reagents used at new concentrator in Kipushi

\begin{tabular}{lll}
\hline Reagent type and concentration & Dosage rate $(\mathrm{g} / \mathrm{t}$ ore $)$ & Daily consumption rate $(\mathrm{kg} / 1750$ tonnes) \\
\hline Slimes dispersant-sodium silicate $20 \%$ & 400 & 700 \\
Frother-Dowfroth or $\mathrm{D}_{250} 100 \%$ & $80-100$ & $140-175$ \\
Modifier-Ammonium sulphate $30 \%$ & 400 & 700 \\
Modifier-Citric acid 20\% & 800 & 1400 \\
Sulphidizer-sodium sulfhydrate $36 \%$ & 10,000 & 17,500 \\
Collector (primary)-potassium amyl xanthate $10 \%$ & 1000 & 1750 \\
Collector (sec.)-mixture gasoil $(90 \%)$ and Rinkalore $(10 \%)$ & 120 & 210 \\
\hline
\end{tabular}

simultaneous recovery of malachite and heterogenite using the excess sulphidizing dosage comparatively to the Kambove Concentrator where the process design is centred on the improved recovery of malachite. It is important pointing out that the talc removal circuit of the NCK has been overhauled in view to float sulphide minerals prior to sulphidization of oxide minerals contained in the feed presently consisting of a blend comprising $30 \%$ sulphides and $70 \%$ oxides.

\section{Management of process wastewaters at Kambove and NCK concentrators}

The Kambove concentrator consumes about $300 \mathrm{~m}^{3}$ of water per hour. About $60 \%$ of the total water flow rate $\left(500 \mathrm{~m}^{3}\right.$ per hour) required by the flotation plant presents mine runoff from an underground mine (SNC-Lavalin International 2003). Compared to the water consumption recorded at the NCK, which utilizes a wet grinding circuit (Autogenous mill), the Kambove concentrator grinding circuit is water-saving because it consumes only about $2.9 \mathrm{~m}^{3}$ of fresh water per ton of ores processed. Indeed, the ROM ores are subjected to a series of crushing and screening enabling the comminuted matter to be delivered to the rod and ball milling throughout a wet section (Lutandula and Banza 2013). However, the circuit implemented at NCK seems more advantageous from environmental viewpoint. Figure 4 schematically outlines the main flows of the wastewater management system

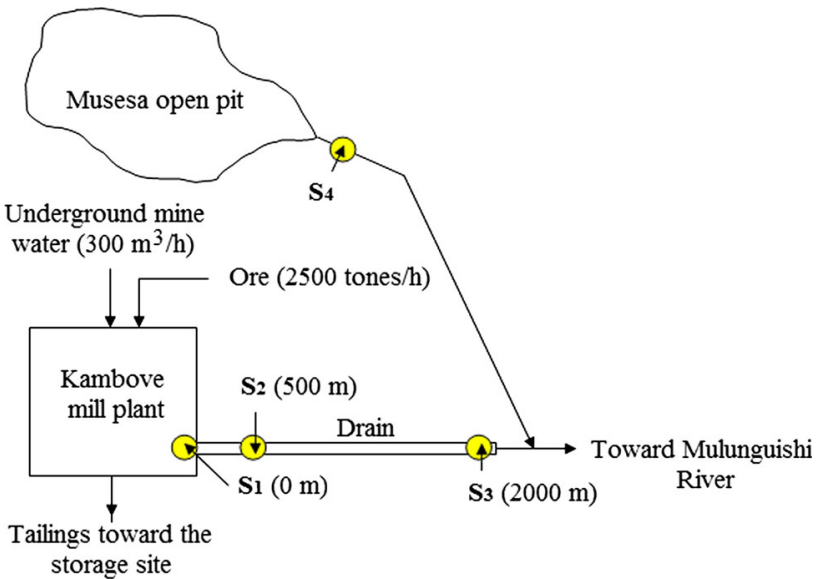

Fig. 4 Wastewater management scheme at the Kambove concentrator with sampling points used in this study

implemented at Kambove concentrator (Lutandula and Banza 2013)

According to recent findings, the Kambove concentrator discharges to the environment two types of flotation wastewaters (Banza 2007; Kanku 2008; Lutandula and Banza 2013). From one hand, these are pulps consisting from cyclone over-flows and tails from the talc removal pre-flotation circuit. On the other hand, one finds wastewaters, which combine spillages from flotation cells, clarified waters from primary and secondary thickening circuits and water from concentrate storage ponds (Banza 2007). The first type of wastewaters joins the flotation tails 
Table 5 Elemental composition of clarified supernatant and settled solids from process water at three sampling points at the Kambove Concentrator

\begin{tabular}{|c|c|c|c|c|c|c|}
\hline \multirow[t]{2}{*}{ Element } & \multicolumn{3}{|c|}{ Concentration of metals $(\mathrm{mg} / \mathrm{L})$ in clarified supernatant } & \multicolumn{3}{|c|}{ Concentration of metals $(\mathrm{mg} / \mathrm{kg})$ in settled solids } \\
\hline & $S 1$ & $S 2$ & $S 3$ & $S 1$ & $S 2$ & $S 3$ \\
\hline $\mathrm{Cu}$ & 0.017 & $<0.01$ & $<0.01$ & 159 & 166 & 182 \\
\hline Co & $<0.01$ & $<0.01$ & $<0.01$ & 40 & 108 & 36 \\
\hline $\mathrm{Ca}$ & 165.90 & 510.80 & 459.20 & 131 & 140 & 117 \\
\hline $\mathrm{Fe}$ & 0.29 & 0.43 & 0.29 & 354 & 346 & 331 \\
\hline $\mathrm{Mn}$ & 0.03 & 0.04 & 0.04 & 1257 & 1323 & 1116 \\
\hline $\mathrm{Pb}$ & $<0.01$ & $<0.01$ & $<0.01$ & 838 & 561 & 315 \\
\hline $\mathrm{Cd}$ & $<0.01$ & $<0.01$ & $<0.01$ & 10 & 10 & 10 \\
\hline $\mathrm{Ni}$ & 0.05 & 0.02 & 0.03 & 128 & 133 & 123 \\
\hline
\end{tabular}

$S 1, S 2$ and $S 3$ - sampling points along the concentrator flow sheet as detailed at Fig. 4

Table 6 Kambove concentrator characteristics of feed water and process wastewater during two sampling campaigns in 2007 and 2008

\begin{tabular}{|c|c|c|c|c|c|}
\hline \multirow[t]{3}{*}{ Components } & \multicolumn{3}{|l|}{ Water entering flotation } & \multicolumn{2}{|c|}{ Process wastewater } \\
\hline & \multirow[t]{2}{*}{ Underground mine water ${ }^{\mathrm{a}}$} & \multicolumn{2}{|c|}{ Musesa open pit water ${ }^{\mathrm{b}}$} & \multirow[b]{2}{*}{$S 1(2007)$} & \multirow[b]{2}{*}{$S 1(2008)$} \\
\hline & & S4 (2007) & S4 (2008) & & \\
\hline $\mathrm{Cu}(\mathrm{mg} / \mathrm{L})$ & 0.70 & 0.02 & $<0.01$ & 0.02 & $0.001-2.18$ \\
\hline Co $(\mathrm{mg} / \mathrm{L})$ & 3.10 & 0.01 & $<0.01$ & $<0.01$ & N.A. \\
\hline $\mathrm{Fe}(\mathrm{mg} / \mathrm{L})$ & 3.40 & 0.36 & 0.61 & 0.29 & $0.39-1.75$ \\
\hline $\mathrm{Zn}(\mathrm{mg} / \mathrm{L})$ & 0.10 & N.A. & $<0.01$ & N.A. & $0.01-1.09$ \\
\hline $\mathrm{Pb}(\mathrm{mg} / \mathrm{L})$ & $<0.05$ & 0.01 & $<0.01$ & $<0.01$ & $0.01-4.12$ \\
\hline $\mathrm{Cd}(\mathrm{mg} / \mathrm{L})$ & $<0.01$ & 0.01 & $<0.01$ & $<0.01$ & $0.005-0.01$ \\
\hline $\mathrm{Ni}(\mathrm{mg} / \mathrm{L})$ & N.A. & 0.023 & 0.03 & 0.05 & $0.02-0.64$ \\
\hline $\operatorname{Mn}(\mathrm{mg} / \mathrm{L})$ & 0.20 & 0.04 & 0.33 & 0.03 & N.A. \\
\hline $\mathrm{Ca}(\mathrm{mg} / \mathrm{L})$ & N.A. & 422.02 & 502.09 & 165.90 & N.A. \\
\hline $\mathrm{pH}$ & 7.80 & 7.65 & 8.12 & 8.98 & $7.33-8.91$ \\
\hline Total hardness $\left({ }^{\circ} \mathrm{F}\right)$ & 28.70 & 25.95 & 29.25 & 26.30 & $24.98-59.41$ \\
\hline $\mathrm{COD}\left(\mathrm{mg} \mathrm{O}_{2} / \mathrm{L}\right)$ & N.A. & 8.05 & 9.27 & 10.48 & $3.99-10.61$ \\
\hline
\end{tabular}

$S 1$ and $S 4$ sampling points along the concentrator flow sheet as detailed at Fig. 1 [sampling campaigns carried out by Banza (2007) and Kanku (2008)]

N.A. analysis not available

${ }^{a}$ Water from Kambove underground mine (SNC-Lavalin International 2003)

b Musesa open pit water is also used in flotation (Fig. 4) which due to collapse of the tailings dam in 1992 are temporary pumped towards a plant spillway (Kalenga et al. 2006; Lutandula and Banza 2013; SNC-Lavalin International 2003). Normally, these wastewaters have to be evacuated towards the Kabambakola storage area. The second wastewaters type is partially sent to a ditch or in total let to join the Mulungwishi River. Table 5 presents an elemental analysis for the clarified supernatant and the solids contained in process water sampled at three points at Kambove concentrator (Banza 2007) and illustrated at Fig. 4. Point $\mathrm{S} 1$ is located inside the flotation circuit, whilst $\mathrm{S} 2$ and S3 are samplings inside the evacuation canal at different distances from the discharge point.
Apart from flotation wastewaters, the Mulungwishi River receives high salinity waters from the Musesa open pit as well. It is worth to mention that flotation wastewaters are not reused at the Kambove concentrator. Table 6 gives idea about the main characteristics of feed water and flotation process waters (Kanku 2008).

Data at Table 5 show slight diminution in metals concentration along the length of evacuation canal, indicating settling phenomena inside the channel, a fact that should be considered when choosing an appropriate water treatment method. This choice should bear as well the physicochemical quality of the feed and process water used by the concentrator Table 6. 


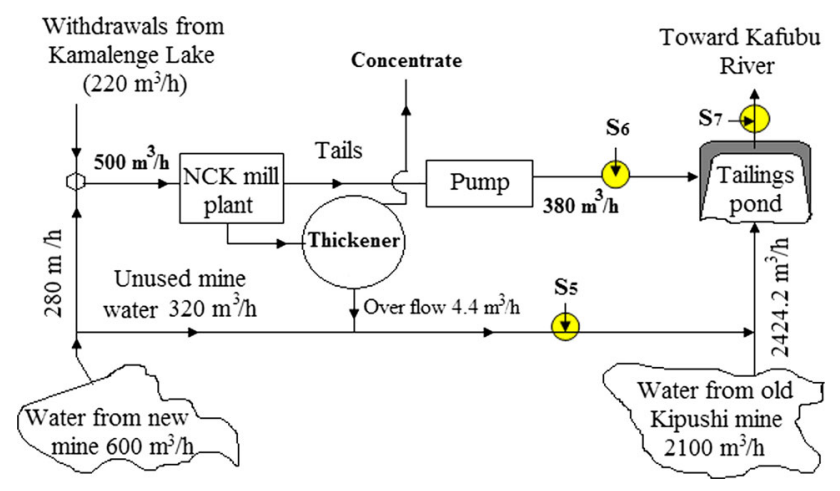

Fig. 5 Water circuit at NCK with solid-liquid streams repartitioning and sampling points used in this study

The NCK is using two principal sources of water for the process: the lake Kamarenge and the waters leaving the Kipushi mines with a total flow rate of about $2700 \mathrm{~m}^{3} / \mathrm{h}$ (Kalenga et al. 2006; SNC-Lavalin International 2003). Figure 5 indicates the water balance of the concentrator based on the currently known mean flow rates.

It is estimated that flotation cycle consumes nearly $500 \mathrm{~m}^{3}$ water per hour, an amount that represents about $8 \%$ of the total water coming from the Kipushi mines. The flow rate of $500 \mathrm{~m}^{3} / \mathrm{h}$ consists from $280 \mathrm{~m}^{3} / \mathrm{h}$ mine water (hardness of $65-80{ }^{\circ} \mathrm{F}$ ) and $220 \mathrm{~m}^{3} / \mathrm{h}$ fresh water pumped from the Kamarenge Lake (hardness of $15^{\circ} \mathrm{F}$ ). Fresh water addition is necessary for neutralizing the elevated hardness of the mine waters. It also enables preventing perturbations on the process functioning (NCK 2006, 2008). In such a way, the tailings pond receives a mixture of supernatants from flotation tails, mine water from the both Kipushi mines and clarified overflow from the concentrate thickener. Hence, the Kafubu River being the ultimate receptor of the clarified waters from the tailings pond receives a variety of wastewaters (Kalenga et al. 2006; SNC-Lavalin International 2003). In addition, the NCK concentrator consumes about $6.8 \mathrm{~m}^{3}$ of fresh water per ton of ore processed, a figure which exceeds nearly 13 times the average quantity of fresh water consumed by the Chilean mineral industry (Bosse et al. 2007) and is well above the average value reported for water consumption per unit copper produced (Mudd 2008).

Table 7 provides results from analysis of the two principal sources of process water at NCK, at two sampling points inside the flotation circuit and at the tailing pond as well (NCK 2006, 2008; Nyrenda 2006). A perusal of the data shown at Table 7 suggests that the water from the old mine is characterized by elevated concentration of copper and sulphate ions. The increased concentration of metals and salinity should be taken into consideration when choosing the optimal proportions of feed water and when selecting the associated water treatment technique as well.
Implication of the two case studies to the effluent management practices in Katanga province

Given the results obtained at Kambove concerning the analysis of wastewaters from the concentrate thickening and dewatering circuits (Table 5), an intermediate pond for wastewater pre-treatment in view removing solids and associated heavy metals via wastewaters settling or clarification can be suggested. The chemical analysis of the clarified process waters shown in Table 7 (the case of $\mathrm{NCK}$ ) is suggesting the option for direct process water return in the milling circuit, likewise practised elsewhere (Charbonnier 2001; Erten-Unal and Wixson 1999). Nevertheless, the prohibiting costs for construction of pumping infrastructure and the necessity for dosing additional reagents for water pre-treatment eliminating the "hindering" effects have been viewed as principal obstacles for implementation of this option by the mineral processing operators in Katanga (SNC-Lavalin International 2003). In endeavouring to establish the optimal conditions for water recycling and the proportion of fresh water addition, it is important to perform real flotation tests evaluating the effects from water quality on flotation results (Johnson 2003a, b; Liu et al. 2013). It should be noted that process water reuse scheme following a simple solid-liquid separation is already implemented at the Mufulira concentrator in neighbouring Zambia (Ng'andu 2001). This established water recycling scheme dates back 1933 and encompasses the return of about $40 \%$ of overflow from the tailings thickener and $1 \%$ from the concentrate thickener back into the grinding circuit (Ng'andu 2001). The mill processes about 300,000 tonnes of sulphide ore on a monthly basis and produces concentrates grading 46-48\% Cu (Fig. 6).

Given the geographical proximity and the climatic conditions similarity, the way in which Mufulira concentrator recycles its process waters could provide for the most of the mineral processing plants in Katanga a quite good example to follow. Moreover, the Mufulira, NCK and Kambove concentrators both utilize xanthates as collectors and mine waters as make-up water for their processes and are located in the African Copper-Belt. However, it is important bearing in minds that the Zambian concentrator reuses water during processing of copper sulphide ores consisting mainly of bornite and chalcopyrite, whilst the Congolese ones treat oxidized copper-cobalt ores essentially in the form of malachite and heterogenite. The copper-cobalt minerals are subjected to sulphidization, showing explicitly a great difference in the ROM ores mineralogical characteristics (NCK 2006, 2008; Ng'andu 2001; Nyrenda 2006). Consequently, the plants flow sheets and the chemical composition of process waters differ substantially. Besides, at the Mufulira concentrator, the recycled process water consists essentially of clarified 
Table 7 NCK characteristics of feed water and process wastewater at two sampling points of the flow sheet and at tailings pond discharge

\begin{tabular}{|c|c|c|c|c|c|c|}
\hline \multirow[t]{2}{*}{ Components } & \multicolumn{2}{|c|}{ Water entering flotation $^{\mathrm{a}}$} & \multirow{2}{*}{$\begin{array}{l}\text { Feed water } \\
(A+B)^{\mathrm{c}}\end{array}$} & \multicolumn{2}{|c|}{ Process water ${ }^{b}$} & \multirow{2}{*}{$\begin{array}{l}\text { Tailings pond } \\
S 7\end{array}$} \\
\hline & Mine & Lake & & $S 5$ & $S 6$ & \\
\hline $\mathrm{Cu}(\mathrm{mg} / \mathrm{L})$ & 1.94 & 0.26 & 1.00 & 0.38 & 0.45 & 1.59 \\
\hline Co $(\mathrm{mg} / \mathrm{L})$ & 0.06 & 0.07 & 0.07 & 0.24 & 0.69 & 0.14 \\
\hline $\mathrm{Fe}(\mathrm{mg} / \mathrm{L})$ & 0.29 & 0.24 & 0.26 & 0.34 & 3.64 & 2.03 \\
\hline $\mathrm{Mn}(\mathrm{mg} / \mathrm{L})$ & 0.09 & 0.04 & 0.06 & 0.40 & 3.96 & 5.01 \\
\hline $\mathrm{Zn}(\mathrm{mg} / \mathrm{L})$ & 1.82 & 0.17 & 0.90 & N.A. & N.A. & N.A. \\
\hline $\mathrm{Ni}(\mathrm{mg} / \mathrm{L})$ & 0.02 & 0.03 & 0.03 & 0.03 & 0.03 & 0.03 \\
\hline $\mathrm{Pb}(\mathrm{mg} / \mathrm{L})$ & 0.06 & 0.04 & 0.05 & 0.09 & 0.08 & 0.08 \\
\hline $\mathrm{Cd}(\mathrm{mg} / \mathrm{L})$ & 0.01 & 0.01 & 0.01 & 0.10 & 0.10 & 0.01 \\
\hline Sulphates (mg/L) & 419.47 & 54.85 & 106.96 & 364.21 & 306.60 & 334.39 \\
\hline $\mathrm{pH}$ & 7.82 & 7.76 & 7.01 & 10.11 & 7.95 & 7.57 \\
\hline Turbidity (NTU) & N.A & N.A. & N.A. & 400.00 & 961.00 & 11.00 \\
\hline Total hardness $\left({ }^{\circ} \mathrm{F}\right)$ & 78.80 & 11.13 & 21.90 & 1.40 & 2.70 & 12.10 \\
\hline Suspended matter (mg/L) & N.A & N.A. & N.A. & 674.00 & 825.00 & 28.00 \\
\hline
\end{tabular}

$A$ mine water accounting nearly for $44 \%$ of the total volume and consisting of the hard component in the feed water, $B$ water from the Lake accounting for $56 \%$ of the total volume and acknowledged as the soft component in the feed water, $S 5$ process water-mixed thickener overflow and mine water (Fig. 5), S6 water accompanying the flotation tails (Fig. 5), $S 7$ tailings pond water (Fig. 5)

N.A. analysis not available

a $\operatorname{NCK}(2008)$

b Nyrenda (2006)

c NCK (2009)

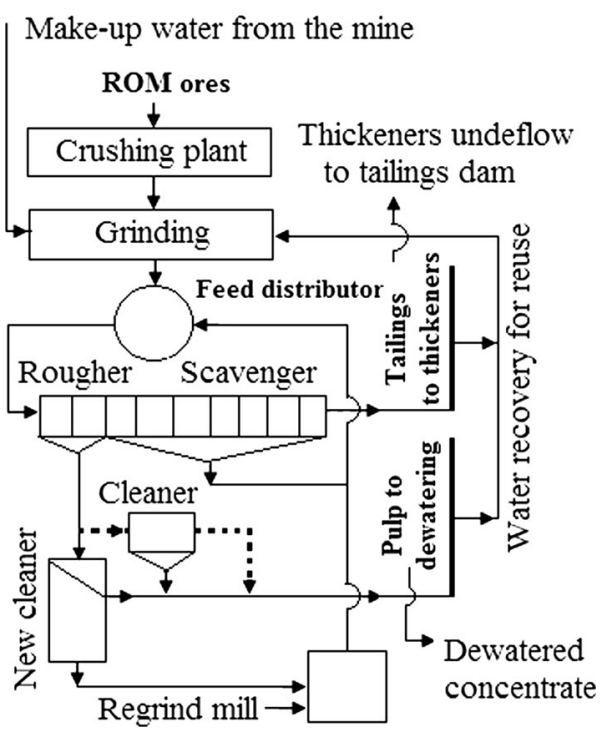

Fig. 6 Mufulira concentrator west side flow sheet and process water management system

overflows after intermediate thickening of tailings, whereas at NCK, significant amount of process water is taken from the Kamarenge Lake. Between 1990 and 1991, the use of higher than usual proportion of water originating from the mine has induced a significant drop in metal recovery by flotation due to the build-up of alkaline earth and sulphate ions resulting in the reagents overconsumption (Bosse et al. 2007; Namita and Natarajan 1998a; Rao and Finch 1989). The NCK is also facing similar situation nowadays; therefore, a judicious selection of the proportion of source waters for the feed water is required. At the Mufulira Concentrator, the worsening in copper recovery through flotation has been also observed due to an increase of the mine water proportion in the feed lowering the milling $\mathrm{pH}$ (Ng'andu 2001). This phenomenon has enhanced galvanic interaction between the sulphide minerals and the cast iron grinding media deteriorating their surface properties resulting in hindrances on the collector absorption process.

Perceived as "low tech" approach for reclamation of mineral processing wastewaters, the biological treatment could prove an interesting option from practical, economical and environmental viewpoint in Katanga, instead of using methods like dissolved air flotation or reverse osmosis (Feofanov et al. 1985; Nedved and Jansz 2006; Puget et al. 2000; Singh et al. 2011; Vymazal 2010; Wawrzak and Cablík 2014). Thus, for removal of residual flotation reagents, a construction of wetlands could be retained as an option, owing to the fact that some key factors like biogeochemical conditions are available or can be achieved in order to stimulate a treatment process through transfer or transformation mechanisms (Namita and Natarajan 1998b; Rodgers and Castle 2008; Vymazal 2011). In such a way, provided flotation pulps are well 
Table 8 Microbiological quality of the NCK process wastewater and the Kipushi mine water

\begin{tabular}{lll}
\hline Microorganism & $\begin{array}{l}\text { NCK process wastewater } \\
\text { Colonies/5 ml }\end{array}$ & $\begin{array}{l}\text { Kipushi underground mine water } \\
\text { Colonies/5 ml }\end{array}$ \\
\hline Nitrosomonas. sp & 2400 & - \\
Pseudomonas & 90,000 & - \\
Nitrobacteria & 80,000 & - \\
Thiobacillus sp & - & 2000 \\
Thiomicrospira sp & - & 850 \\
Gallionella sp & - & 600 \\
\hline
\end{tabular}

Mukudi and Shengo (2011) clarified in the tailing ponds along with a sufficient removal of the fine suspended solids, a subsequent biological treatment in a constructed wetland or with reactive barriers could be sought with the aim to eliminate the residual flotation reagents and their decomposition products.

In the case of wastewaters coming from the NCK, due to their high colour ( $>550 \mathrm{TCU})$, turbidity (400-961 NTU) and solid matter content $(674-825 \mathrm{mg} / \mathrm{L})$, clarification could be used as a pre-treatment step prior to biological treatment. This is supported by findings of Nyrenda (2006) who has observed a significant drop in concentrations of copper $(75 \%)$, iron $(86 \%)$, manganese $(81.6 \%)$, sulphates $(35.6 \%)$ and solid matter (nearly $100 \%)$ following wastewater settling in tailings pond. Similar trend has been noted for salinity (46\%), electric conductivity (46\%) and colour $(98 \%)$ in flotation wastewaters. Data shown at Table 6 are suggesting that at Kambove, the removal of the associated solids could be also achieved inside the clarification pond, the latter one being viewed as a kind of wastewater pre-treatment step.

Another bio-treatment option that could be envisaged in short term is to explore the possibility of transforming the currently used tailings ponds into a large lagoon functioning as bioreactor (Nyrenda 2006). Namita and Natarajan (1998b) have already indicated the possibility to degrade biologically certain surfactants used in flotation (dodecylamine or diamine, sodium isopropylxanthate and sodium oleate) with Bacillus polymyxa under alkaline conditions. Nevertheless, the success of the above-proposed treatment and recycling schemes for the mineral industry in Katanga requires some important prerequisites to be fulfilled. Above all, the existence of conditions for bio-augmentation or bio-stimulation in order to enhance the subsequent degradation or digestion of surfactants by bacteria should be guaranteed. The presence of both the heterotrophic and autotrophic bacteria (Table 8) in the NCK process wastewaters along with that of the chemoautotrophic bacteria in waters from the Kipushi mine constitute a real incentive to suggest the biological treatment as the best option concerning the reclamation of wastewaters from the processing of copper-cobalt oxide ores by flotation (Mukudi and Shengo 2011; Smith and Scott 2005).
Moreover, after the addition of oxygen, nitrogen- and phosphate-bearing nutrients to $200 \mathrm{~mL}$ of the NCK process wastewater together with its inoculation with $2 \mathrm{~mL}$ of the Kipushi mine water (source of bacteria) followed by the $\mathrm{pH}$ adjustment at 2.51 and incubation for $36 \mathrm{~h}$ at $30^{\circ} \mathrm{C}$, an exponential growth of the chemolithotrophic bacteria was noticed bringing their number of colonies from 3475 to 60,000 (Mukudi and Shengo 2011). Similarly, the pollutants concentrations significantly were dropped in wastewater subjected to treatment to as low as $0.0 \mathrm{mg} /$ $\mathrm{L} \mathrm{Cu} ; 0.0 \mathrm{mg} / \mathrm{L} \mathrm{Co} ; 0.0 \mathrm{mg} / \mathrm{L} \mathrm{Fe} ; 0.024 \mathrm{mg} / \mathrm{L} \mathrm{Zn}$ and $0.130 \mathrm{mg} / \mathrm{L} \mathrm{CO}_{3}{ }^{2-}$ (Mukudi and Shengo 2011). It is important pointing out that the concerned biological treatment has been utilized as a polishing stage following the raw process wastewaters $(3.187 \mathrm{mg} / \mathrm{L} \mathrm{Cu} ; 0.338 \mathrm{mg} /$ $\mathrm{L} \mathrm{Co} ; 0.972 \mathrm{mg} / \mathrm{L} \mathrm{Fe} ; 0.213 \mathrm{mg} / \mathrm{L} \mathrm{Zn}$ and $15.150 \mathrm{mg} /$ $\mathrm{L} \mathrm{CO}_{3}{ }^{2-}$ ) treatment comprising the clarification using a flocculent-assisted sedimentation of colloids followed by the removal of heavy metals by precipitation with chemicals $\left(\mathrm{Na}_{2} \mathrm{CO}_{3}\right.$ and $\left.\mathrm{Na}_{2} \mathrm{~S}\right)$.

The use of a constructed wetland system could be interesting option when considering the presence of sulphate ions in the process wastewaters and in the mine waters. Besides, the metal accumulating plants such as Typha latifolia, Phragmites australis, Eichhornia crassipes, Lamnia minor and other macrophytes are present in the rivers used as spillways for flotation wastewaters (Obreque-Contreras et al. 2015; Shazia Iram et al. 2012; Vymazal 2011).

\section{Conclusion}

The present study was undertaken with the aim to review the most common practices in wastewaters treatment and recycling of process waters during minerals processing and to evaluate the feasibility of their implementation in the local context of the Katanga region which is an area of intensive mining activities since several decades.

Considering the warm climatic conditions which characterize the Katanga province during practically 8 months 
per year together with the heterotrophic and chemolithotrophic bacteria presence in wastewaters, the implementation of biological treatment inside the tailings pond or establishment of constructed wetland systems after the pond could be suggested as an immediate step for treatment and eventual water reuse in the milling process. This suggestion is based on the analysis of the existing flotation and process water schemes at Kambove and NCK concentrators as specific case studies as well as on the results accumulated both elsewhere and in the local context by the researchers interested in the management of wastewaters. The bio-treatment and recycling of wastewaters from flotation of copper ores are expected to enable enhancing the management practices in Katanga through the lowering of the mineral industry footprint on the environment, the safeguarding of watercourses presently used as spillways for flotation effluents and the sustainable use of water resources.

Acknowledgments We are gratefully thanking Professor Stoyan Gaydardzhiev from the ArGEnCo Department of the Faculty of Applied Sciences, The University of Liege in Belgium for having proofread the initial manuscript of the present research. The inorganic chemists Kanku and Banza, respectively, working at the Congolese of Office of Control and the Kakanda Concentrator laboratory are gratefully acknowledged for their involvement in the gathering of the data used during the writing of this paper.

\section{References}

Abramov AA (2005) Russian perspective on indicator of sustainability for flotation processing of minerals. In: Villas Boas RC et al (eds) A review on indicators of sustainability for the minerals extraction industries. CETEM/MCT/CNPq/CYTED/IMPC, Rio de Janeiro, pp 209-226

Anastassakis G, Karageorgiou K Paschalis M (2004) Removal of phosphates species from solution by flotation. In: Gaballah I et al (eds) Proceedings of "Rewas 04": global symposium on recycling and clean technology, vol II, 26-28 Sept 2004, Spain, pp 1147-1154

Anderson J (2000) The environmental benefits of water recycling and reuse, Water Science and Technology. Water Supply 3(4):1-10

Awaleh MO, Soubaneh YD (2014) Waste water treatment in chemical industries: the concept and current technologies. Hydrol Curr Res 5(1):1-12

Banyak D (1998) Frothers, bubbles and flotation, a survey of flotation milling in the twentieth-century metal industries, US government printing office 1999-0-773-551. National Park Service, Intermountain support office, Denver, pp 1-92

Banza M (2007) Environment impact assessment of liquid effluents at the Kambove concentrator. In: Project report Department of Chemistry, Faculty of sciences. University of Lubumbashi, pp 21-34

Boeglin J (1974) Progrès realisés dans la clarification des eaux résiduaires et le séchage mécanique des boues par l'emploi de polymères organiques de synthèse. Pure Appl Chem 37:343-374

Bosse M, Schneider H Cortina J (2007) Treatment and reutilization of liquid effluents of copper mining in desert zones water sustainability and integrated water resource management. In: The preliminary program for 2007 annual meeting. http://aiche. confex.com/aiche/2007/preliminaryprogram/abstract_101082. htm. Accessed 18 Jan 2016

Chadwick J (2008) CAMEC-The cobalt champion, Reports on what is today probably the leading cobalt miner in the world. International Mining, pp 8-16

Chadwick J, Cattaneo B (2005) Tails of the DRC, international mining 1(3). Friary Press, Dorset, pp 23-27

Chadwik J (2009) Copper recovery. International mining, pp 23-30

Charbonnier P (2001) Management of mining, quarrying and oreprocessing waste in the European Union. In: Study made for DG Environment European Commission, BRGM/RP-50319-FR, pp 51-67

Coakley GJ (2001) The mineral industry of Congo (Kinshasa). U.S. Geological survey minerals yearbook, pp 27.1-27.7

Coetzer G, du Preez HS, Bredenhann R (2003) Influence of water resources and metal ions on galena flotation of Rosh Pinah ore. J S Afr Inst Min Metall 13:193-207

Crowson P (2006) The copper industry-raw material scarcity as a risk of conflict and an impediment for development lessons learned, facts, outlook. In: Expert workshop, 21-22 Sept 2006, Berlin, Germany, pp 1-12

Department of Resources, Energy and Tourism, Water Management (2008) Leading practice-sustainable development a program for the mining industry. Australian Government, pp 1-102

Dibrov I, Voronin N, Klemyatov A (1998) Froth flotoextraction, a new method of metal separation from aqueous solutions. Int $\mathbf{J}$ Miner Process 54:45-58

Digby Wells and Associates (2008) Kalukundi copper cobalt project environmental and social impact assessment. In: Report on the tailings storage facility and the waste rock dumps (rev 1). Envirolution consulting (PTY) Ltd, pp 1-33

Dillon P (2000) Water reuse in Australia: current status projections and research. In: Proceedings on water recycling Australia 2000. Adelaide, 19-20 Oct 2000, pp 99-104

Dobson RS, Burgess JE (2007) Biological treatment of precious metal refinery wastewater: a review. Miner Eng 20:519-532

Dolnicara S, Hurlimann A, Grün B (2012) Water conservation behavior in Australia. J Environ Manag 105:44-52

EPA (1994) Design and evaluation of tailings dams. Technical report EPA 530-R-94-038 NTIS PB94-201845 U.S. environmental protection agency. Office of solid waste special waste branch, Washington, DC 20460, pp 3-4

Erten-Unal M, Wixson B (1999) Biotreatment and chemical speciation of lead and zinc mine/mill waste-water discharges in Missouri, USA. Water Air Soil Pollut 116:501-522

European Environmental Agency (2009) Water resources across Europe-confronting water scarcity and drought. EEA Report No. 2/2009. Copenhagen, pp 9-55

Exall K (2004) A review of water reuse and recycling, with reference to Canadian practice and potential: 2 Applications. Water Qual Res J Can 39:13-28

Fatta D, Kythreotou N (2005) Water as valuable water resourceconcerns, constraints and requirements related to reclamation, recycling and reuse. In: Proceedings of IWA international conference on water economics, statistics, and finance. Rethymno, Greece, pp 8-10

Feofanov VA, Pilat BV, Zhdanovich LP, Romanenko AG, Lukhanin BS, Donets OV, Korobochkin VP (1985) Process and apparatus for purifying effluents and liquors. US Patent 525, 254, 25 June 1985, pp $1-10$

Fu F, Wang Q (2011) Removal of heavy metal ions from wastewaters: a review. J Environ Manag 92:407-418

Galil N, Levinsky Y (2007) Sustainable reclamation and reuse of industrial waste-water including membrane bioreactor technologies: case studies. Desalination 202:411-417 
Garcia J, Rousseau DPL, Morato J, Lesage E, Matamoros V, Bayona JM (2010) Contaminant removal processes in subsurface-flow constructed wetlands: a review. Crit Rev Env Sci Technol 40:561-661

Gaydardjiev S, Hadjihristova M, Tichy R (1996) Opportunities for using two low-cost methods for treatment of metal bearing aqueous streams. Miner Eng 9:947-964

Groudeva V (2001) Remediation of metal pollutants by sulfatereducing bacteria. In: Kujumdzieva A (ed) Environment protection and biotechnology-innovative aspects national bank for industrial microorganisms and cell cultures vocational training programme. BioINEP published series, Sofia, pp 1-158

Iram Shazia, Ahmad Iftikhar, Riaz Yousaf, Zahra Ayesha (2012) Treatment of waste water by Lemna minor. Pak J Bot 44(2):553-557

Jennett J, Wixson B (2005) Geochemistry, mining and the environment. Miner Environ 5:36-53

Johnson NW (2003) Issue in maximization of recycling of water in a mineral processing plant. In: Water in mining conference, Brisbane, Queensland, 13-15 Oct 2003, pp 239-245

Johnson R (2003) Water use in industries of the future: steel industry. U.S. Department of Energy Office of Energy Efficiency and Renewable Energy. Industrial Technologies Program, pp 62-96

Journal Officiel de la République Démocratique du Congo (2003) Décret $n^{\circ}$ 038/2003 du 26 mars 2003 portant Règlement minier. Kinshasa, pp 1-179

Kalenga NM, Frenay J, Mukendi K, De Donato P, Kaniki TA (2006) Inventory of sites of production, storage and disposal of mineral wastes in Katanga and assessment of their environmental impacts. A report related to a scientific project of cooperation (2005, No. 6312PS508) between the University of Lubumbashi (UNILU), the University of Liege (ULg) and the National Polytechnic Institute of Lorraine (INPL) funded by the French speaking countries Academic Agency, pp 1-217

Kanku M (2008) Survey on possibilities of recycling flotation wastewater at the Kambove concentrator. Project report Department of Chemistry Faculty of Sciences. University of Lubumbashi, pp 32-61

Katwika NC (2012) Contribution à l'amélioration des performances du nouveau concentrateur de Kipushi en RDC Application de la concentration gravimétrique. Thèse de doctorat, Faculté Polytechnique de Mons Service de Génie Minier, Université de Mons, pp 4-16, 23-37

Kilborn Inc (1999) Review of passive systems for treatment of acid mine drainage. Phase II May 1996, Mend report 3.14.1 revised in 1999 and prepared for the Mine Environment Neutral Drainage (MEND) program. Toronto, pp 1-79

Kunze C, Gunter G, Küchler A (2007) Management of passive biological water treatment systems for mine effluents. In: Marmiroli $\mathrm{N}$ et al (eds) Advanced science and technology for biological decontamination of sites affected by chemical and radiological nuclear agents. Springer, Berlin, pp 177-195

Laurenson S, Kunhikrishnan A, Bolan NS, Naidu R, McKay J, Keremane G (2010) Management of recycled water for sustainable production and environmental protection: a case study with Northern Adelaide Plains recycling scheme. Int J Environ Sci Dev 1(2):176-180

Levay G, Smart R, Skinner W (2001) The impact of water quality on flotation performance. J South Afr Inst Min Metall 111:69-76 III-IV

Liu Wenying, Moran CJ, Vink Sue (2013) A review of the effect of water quality on flotation. Miner Eng 53:91-100

Loshi K (2012) Étude rétrospective de la pollution due au stockage des tailings de la concentration des minerais du cuivre par séparation en milieu dense $(D M S)$. Rapport Préliminaire Département de Chimie Faculté des Sciences. Université de Lubumbashi, pp 1-44
Lutandula MS, Banza M (2013) Recovery of copper and cobalt through reprocessing of tailings from flotation of oxidized ores. J Environ Chem Eng 1:1085-1090

Lutandula MS, Kalenga NM (2014) Perturbations from the recycled water chemical components on flotation of oxidized ores of copper: the case of bicarbonate ions. J Environ Chem Eng 2:190-198

Malkin V, Kuzin V (2001) Purification of industrial waste waters using reagents. Chem Pet Eng 37:338-343

Mawson West Ltd (2011) Annual information form for the year ended June 30, 2011. The Dikulushi Mine and Kapulo project, pp 13, $22-24,30-32$

Mudd GM (2008) Sustainability reporting and water resources: a preliminary assessment of embodied water and sustainable mining. Mine W Environ 27:136-144

Mukudi EL Shengo LM (2011) Improvement of methods used in the management of the process wastewater from flotation of coppercobalt oxide ores at the new concentrator in Kipushi. An interim report of a research project carried out by the Chemistry Department, Faculty of Sciences. University of Lubumbashi, DRC, pp 1-20

Mulligan CN, Gibbs BF (2003) Innovative biological treatment processes for wastewater in Canada. Water Qual Res J Can $38: 243-265$

Muzenda E (2010) An investigation into effect of water quality on flotation performance. World Acad Sci Eng Technol 69:237-241

N'Sakila MG (2008) Commentary: the Chinese presence in Lubumbashi DRC. In: Herman et al (eds) China and the Democratic Republic of Congo: partners in development? The China Monitor, Issue 34, The Centre for Chinese Studies Faculty of Arts. University of Stellenbosch, pp 1-16

Namita D, Natarajan K (1998a) Biological removal of some flotation collector reagents from aqueous solutions and mineral surfaces. Miner Eng 11:717-738

Namita D, Natarajan K (1998b) Biodegradation of some organic flotation reagents by Bacillus polymyxa. Biorem J 2:205-214

NCK (2006) Technical database 2006-CRM and ARA. In: Mining Company of South Katanga (CMSK). Kipushi, DRC, pp 1-47

NCK (2008) Technical Service database-CRM and ARA. Mining Company of South Katanga (CMSK), Kipushi, DRC, pp $142-159$

NCK (2009) Technical report prepared by the Laboratory Analytical Research unit (ARA). Mining Company of South Katanga (CMSK), Kipushi, DRC, p 7

Nedved M, Jansz J (2006) Waste water pollution control in the Australian mining industry. J Clean Prod 14:1118-1120

Ng'andu D (2001) The effect of underground mine water on performance of the Mufulira flotation process. J S Afr Inst Min Metall 101:367-380

Norgate T, Lovel R (2004) Water use in metal production: a life cycle perspective. Report DMR-2505. CSIRO Minerals, Sept 2004, pp 15-16

Nyrenda M (2006) Impact from the (CMSK) wastewaters diversion upon the Kafubu river water quality. Project report Department of Chemistry, Faculty of Sciences, University of Lubumbashi, pp 16-21

Obreque-Contreras J, Pérez-Flores D, Gutiérrez P, Chávez-Crooker P (2015) Acid mine drainage in Chile: an opportunity to apply bioremediation technology. Hydrol Curr Res 6(3):1-8

Otadi N, Hassani AH, Javid AH, Khiabani FF (2011) Oily compounds removal in wastewater treatment system of Pars oil refinery to improve its efficiency in a lab scale pilot. J Food Agr Environ 9(1):725-729

Oudshoorn H (1997) The pending 'water crisis'. Geo J 42:27-38

Potvin R (2004) Réduction de la toxicité des effluents des mines de métaux de base et précieux à l'aide de méthodes de traitement 
biologique. Rapport de synthèse environnementale, Université du Québec en Abitibi-Témiscamingue, pp 7-20

Puget F, Melo M, Massarani G (2000) Waste-water treatment by flotation. Braz J Chem Eng 17:1-7

Rao S, Finch J (1989) Review of water re-use in flotation. Miner Eng 2:65-85

Rodgers JH, Castle JW (2008) Constructed wetland systems for efficient and effective treatment of contaminated waters for reuse. Environ Geosci 15(1):1-8

Rodrigues R, Rubio J (2007) DAF-dissolved air flotation: potential applications in the mining and mineral processing industry. Int $\mathrm{J}$ Miner Process 82:1-13

Rubio J, Souza M, Smith R (2002) Overview of flotation as a wastewater treatment technique. Miner Eng 15:139-155

Rubio J, Carissimi E, Rosa J (2007) Flotation in water and wastewater treatment and reuse: recent trends in Brazil. Int J Environ Poll 30:193-207

Rulkens H (2007) Sustainable development in industry by closing cater loops: technological aspects and expected future developments. In: Mournighan R et al (eds) Chemistry for the Protection of the Environment, vol 4. Springer, Environ Sci Res 59: 223-253

Saavedra C (2012) The beginning of the water pumping cycle in the pier sector Minera Esperanza Antofagasta. In: Anthony Hodge (eds) Water management in mining: a selection of case studies. The International Council on Mining and Metals report, London, pp 12-13

Sandenbergh RF, Wei Y (2007) The influence of water quality on the flotation of the Rosh Pinah complex lead-zinc sulfides. In: The 4th Southern African Conference on base metals. The S Afr Inst Min Metall, pp 45-55

Schoengold K, Zilberman D (2008) Creating a policy environment for sustainable water use. In: Wiegandt E (ed) Mountains: sources of water sources of knowledge. Springer, Berlin, pp 305-326

Shammas NK, Wang LK, Hahn HH (2010) Principles of air flotation technology. In: Wang LK et al (eds) Flotation technology, handbook of environmental engineering, vol 12., Humana PressSpringer, London, pp 137-145

Shengo LM, Gaydardzhiev S, Kalenga NM (2014) Assessment of water quality effects on flotation of copper-cobalt oxide ore. Miner Eng 65:145-148

Singh R, Kumara A, Kirrolia A, Kumar R, Yadav N, Bishnoi NR, Lohchab RK (2011) Removal of sulphate, COD and Cr(VI) in simulated and real wastewater by sulphate reducing bacteria enrichment in small bioreactor and FTIR study. Biores Technol 102:677-682

Slatter KA, Plint ND, Cole M, Dilsook V, De Vaux D, Palm N, Oostendorp B (2009) Water management in Anglo Platinum process operations: effects of water quality on process operations. In: Abstracts of the international mine water conference organized by Cilla Taylor Conferences. 19th-23rd Oct 2009, Pretoria (South Africa), pp 46-55

Smith PG, Scott JG (eds) (2005) Dictionary of water and waste management, 2nd edn. IMW Publishing, Elsevier, London, pp $16,34,38,79,116,186,230,252,286,288,342$

SNC-Lavalin International (2003) Étude sur la restauration des mines de cuivre et de cobalt en République Démocratique du Congo, Rapport d'étude initial NM-6708 (603082), Montréal, pp 1-229
Stapelfeldt F, Fernandes Lima R (2001) Recycling of process water containing amines in the reverse flotation of iron ores. IMWA Symposium 2001, Belo Horizonte, pp 1-10

Sterritt R, Lester J (1979) The microbiological control of mine waste pollution. Miner Environ 1:45-47

Swartz B, Donegan S, Amos S (2009) Processing considerations for cobalt recovery from Congolese copperbelt ores. In: Hydrometallurgy conference 2009. The S Afr Inst Min Metall, pp 385-400

Sychkov V, Bochkarev G (1976) Use of water in flotation of transbaikal fluorite ores. Translated from Fiziko-Tekhnicheskie Problemy Razrabotki Poleznykh Iskopaemykh, vol 4, July-Aug 1976, pp 66-72

TFM (2010) Addendum to the environmental and social impact assessment (EISA) for the proposed mine and process plant expansion at Tenke Fungurume Mining Katanga province Democratic Republic of the Congo "Invitation to comment" a background information document. In: Report No: 11906-89453, April 2010, pp 1-7

The Netherlands institute for Southern Africa (NISA) (2006) Governance mining and the transitional regime in the Democratic Republic of Congo. The Netherlands, pp 1-79

UNESCO (2003) The water crisis: how has it come to this? In: Natural sciences quarterly newsletter, a world of science, vol 5, Oct-Dec 2003, pp 2-5

Vande Weghe J, Franssen J, Kalambay G, Kramkimel J, Musibono D (2005) Profil Environnemental (PEP) de la République Démocratique du Congo rapport provisoire. Report from a contract $\mathrm{N}^{\circ}$ 2005/105393-European union rural and agriculture temporary association (EURATA), pp 11, 42-43, 48, 154-156

Verlinden P, Cuypers L (1956) Union Minière du Haut Katanga 1906-1956. Cinquantième Anniversaire de sa création VROMATS S.A. Printing House, Meersmans, Brussels, pp 89-131, 148

Vymazal J (2010) Constructed wetlands for wastewater treatment. Water 2:530-549

Vymazal J (2011) Plants used in constructed wetlands with horizontal subsurface flow: a review. Hydrobiologia 674:133-156

Welz M, Baloyi N, Deglon D (2007) Oil removal from industrial waste-water using flotation in a mechanically agitated flotation cell. Water SA 33:453-458

World Bank Group (1999) Pollution prevention and abatement handbook 1998-towards cleaner production. The International Bank for Reconstruction. The World Bank, Washington, DC, USA, pp 267-277

Wotruba H (2008) Water energy and masses workshop "Sustainability in mineral processing". In: XXIV International mineral processing congress, Beijing, 24-28 Sept 2008

Xingyu L, Bowei C, Wenjuan L, Yongsheng S, Jiankang W, Dianzuo W (2013) Recycle of wastewater from lead-zinc sulfide ore flotation process by ozone/BAC technology. J Environ Protect $4: 5-9$

Wawrzak D, Čablík V (2014) Microbiological decomposition of sulphates in reduction of cod in diary industry wastewater. J Polish Miner Eng Soc 15:269-274

Żak S (2012) Treatment of the processing wastewaters containing heavy metals with the method based on flotation. Ecol Chem Eng S 19(3):433-438

Zeman C, Rich M, Rose J (2006) World water resources: trends, challenges and solutions. Rev Environ Sci Biotechnol 5:333-346 